Regulatory Institutions Network

\title{
'RESETTING THE RELATIONSHIP' IN INDIGENOUS CHILD PROTECTION: PUBLIC HOPE AND PRIVATE REALITY
}

Mary Ivec, Valerie Braithwaite and Nathan Harris

Occasional Paper 14

November 2009 


\section{'Resetting the Relationship' in Indigenous Child Protection: Public Hope and Private Reality}

Mary Ivec, Valerie Braithwaite and Nathan Harris

Regulatory Institutions Network

Australian National University

6 November 2009

ISBN 978-0-9803302-7-4 (online) 
(C) Regulatory Institutions Network, Research School of Pacific and Asian Studies, Australian National University 2009

National Library of Australia

Cataloguing-in-Publication data:

'Resetting the Relationship' in Indigenous Child Protection: Public Hope and Private Reality

ISBN 978-0-9803302-7-4 (online)

1. Aboriginal Australians--Child welfare. 2. Children, Aboriginal Australian--Government policy.

362.76809915

Disclaimer

This article has been written as part of a series of publications issued from the Regulatory Institutions Network. The views contained in this article are representative of the author only and not of the Australian National University or any funding partner. 


\author{
By Mary Ivec, Valerie Braithwaite and Nathan Harris \\ Regulatory Institutions Network, The Australian National University \\ Working Paper 14
}

\begin{abstract}
A qualitative study was undertaken to explore the private realities of Indigenous parents and self-identified carers who had experiences with child protection authorities. Semi-structured interviews focused on the nature of the relationship between parents and child protection authorities, how these regulatory encounters served to enlist or dissolve co-operation and how child-focused outcomes could be delivered. Data from interviews with forty-five Indigenous parents and self-identified carers in three separate jurisdictions in Eastern Australia revealed a paradox for authorities. Descriptions of encounters with authorities were overwhelmingly negative and challenged the public hope for reconciliation between government and Indigenous Australians. Enforcement strategies were experienced as confusing, threatening and coercive, undermining parenting morale and informal care capacity. On the other hand a positive role was acknowledged for child protection authorities and there seemed interest in working with such authorities, albeit with different strategies from those currently experienced. The need for dialogue, trust and partnerships involving informal care networks emerges from analysis of the data. The paper discusses how this progression might be facilitated by principles of restorative justice and responsive regulation.
\end{abstract}

Keywords: Indigenous Child Protection, Public Hope, Restorative Justice, Responsive Regulation, Respect, Community Engagement. 


\section{Introduction}

The ways in which contemporary child protection is perceived by Indigenous Australians is bound to be framed by historical experience. Historical accounts of the relationship between Indigenous people and State child protection services, or as they were often referred to 'the welfare', have been well documented (HREOC 1997; Haebich 2000; Cunneen \& Libesman 2000; Manne 2006; Tilbury 2008). The removal of children from Aboriginal parents was government policy until the 1970s (HREOC 1997). In the mid-1970s pressure from newly formed Aboriginal organizations including Aboriginal Legal Services whose assistance was being sought by parents who had lost, and wanted back, their children forced a reappraisal of removal and placement practice during the 1980s (Haebich 2000). In April 1997 a Royal Commission's landmark report, Bringing Them Home, documented the forced separation of Aboriginal children from their families and the devastating consequences of removal policies for the 'Stolen Generations'. Fifty-four recommendations were made, one being that reparation be made in recognition of the history of gross violations of human rights. The first of five principles which guided the reparation measures was an acknowledgement and apology to individuals, families, communities and descendants of those forcibly removed as children. Almost eleven years later, in February 2008, a formal apology was issued by the Australian Government for what was acknowledged as the wrongful removal of children.

The National Apology was described by the Prime Minister as 'a starting point for reconciliation and the beginning of a bridge of respect between Indigenous and nonIndigenous Australians ${ }^{1}$, Described as a 'seminal moment in the nation's history ${ }^{2}$ ' by Pat Dodson, public hope reverberated for a future where the nation could 'turn a new page in

\footnotetext{
${ }^{1}$ http://www.pm.gov.au/node/5307

2 http://www.theaustralian.news.com.au/story/0,25197,23205327-5013172,00.html
} 
Australia's history. ${ }^{3}$ The Bringing Them Home stories finally had a national and an international audience, their impact palpable. According to the Prime Minister, to deny these stories, to leave them as 'little more than an interesting sociological phenomenon'4 was to deny the fact that decisions of parliaments and governments left generations of human beings deeply damaged. This damage called for public acknowledgment and apology. 'Moving forward with confidence to the future ${ }^{5}$ was the promise this seminal moment offered the nation. In this way, public hope was invoked in relation to reconciliation and being truly equal partners with Indigenous Australians. How then does this public hope coalesce with the private reality of Indigenous parents and carers who are at the receiving end of child protection intervention and regulation in the twenty-first century?

Little data have been published on the contemporary experiences of Indigenous children and their carers with child protection systems yet these stories too 'cry out to be heard. ${ }^{6}$ The Stolen Generations is assumed to be in the past, but statistics on the removal of children from their families remain cause for concern. The percentage of children on care and protection orders continues to be proportionally higher for Indigenous than non-Indigenous children ${ }^{7}$. Indigenous children make up 4.5 per cent of the Australian population aged 0-15 years (ABS 2008), yet they account for 29 per cent of all children in out-of-home care. Reasons given for removal by child protection authorities are abuse and neglect, often associated with poverty, substance abuse and homelessness. All of these conditions disproportionately affect Indigenous Australians (Productivity Commission 2009; AIHW 2009). Reports which deal

\footnotetext{
${ }^{3}$ http://www.pm.gov.au/node/5952

${ }^{4}$ ibid

5 ibid

${ }^{6}$ ibid

${ }^{7}$ The rate of Indigenous children in out-of-home care was almost 9 times the rate of nonIndigenous children, 41.3/1,000 Indigenous children compared to 4.6/1000 for nonIndigenous children (AIHW 2009).
} 
with Aboriginal services emphasize poor outcomes in all areas of human services more broadly (Baldry, Green \& Thorpe 2002). Recent government reviews into child protection identify multiple recurring system failings. ${ }^{8}$ These forums have presented parents and carers some opportunity to share their experiences of and concerns with the child protection system but it is unclear how Indigenous Australians are experiencing these policies given the history of Indigenous child removal in this country. Publicly released submissions made to the Wood Inquiry for example indicate that four submissions by Indigenous organizations at least were considered by the Inquiry. The proportion of submissions to the Inquiry made by Indigenous people is not known as this information appears not to have been kept by the Inquiry ${ }^{9}$.

This paper will contribute to filling this knowledge gap. Interviews conducted with a selfselected sample of parents and carers of Indigenous children were analysed with a view to understanding Indigenous perceptions of the integrity of child protection agencies. Integrity refers to an organization's capacity to meet its objectives, all the while supported by the democracy and responsive to the democracy in terms of accountability, transparency and procedural justice (Braithwaite 2003, 2009; Selznick 1992, Tyler 1990, 1997). An organization can be said to have low integrity when the public is unclear and confused about its purpose, when there are reports of unfair and non-transparent processes and outcomes, and when there are perceptions of a disconnect between the values of the organization and the public. Perceptions that an authority has low integrity undermine cooperation (Braithwaite 2009; Tyler 2008). Integrity failings would not augur well for resetting the relationship of Indigenous families with child protection authorities. This paper explores perceived integrity through analysing interviews with parents and carers of Indigenous children in terms of three

\footnotetext{
${ }^{8}$ Vardon 2004, Ford 2007, Wild \& Anderson 2007, Mullighan 2008, Wood 2008, Hope 2008.

${ }^{9}$ Advice provided verbally by N.S.W. Department of Justice and Attorney General staff.
} 
research questions: (a) How was the style of engagement of child protection staff perceived and interpreted, in particular did parents and carers think they were treated with respect and dignity? (b) What do parents and carers understand of the child protection authority's objectives and purpose? (c) What do parents and carers regard as the blind spots of child protection authorities? This last question enabled a preliminary examination of the more fundamental issue of whether parents and authorities share the same values and standards in relation to parenting.

In addition to these questions, two propositions were examined that may block in the first case, and facilitate in the second any progress in increasing co-operation between Indigenous Australians and child protection authorities. The first proposition is that contemporary child protection authorities are perceived by Aboriginal families as 'a threat to our freedom'. This perception is historically based in the coercive removal of previous generations of children from Aboriginal families.

The second proposition is that Aboriginal families are committed to the government's objective of keeping children safe and accept that the State has a role in protecting children from danger. This proposition is grounded in the observation of a more fundamental human condition - the love of parents and grandparents for their children. Regardless of race and history, concern for the well-being of children leads to in principle acceptance of a government child protection system. Evidence presented to the Wood Inquiry demonstrates examples of Indigenous parents working co-operatively ${ }^{10}$ with authorities when child safety concerns exist.

10

http://www.lawlink.nsw.gov.au/lawlink/Special_Projects/11 splprojects.nsf/vwFiles/DOC080 424.PDF/\$file/DOC080424.PDF pp. 14-15 \& pp. 53-54 


\section{Methodology of study}

In 2008, in depth interviews were conducted with forty-five Indigenous parents and selfidentified carers from Canberra, New South Wales and Queensland as part of a study on 'Building Capacity in Indigenous Child Protection.' Those interviewed were asked to tell their story. They were asked to describe how they were treated by child protection services, were they helped and what were their ideas for making the system work better. In general, the interviewer adopted a listening role, interrupting only for purposes of clarification or in order to steer discussion back to experiences with and expectations/understandings/perceptions of child protection authorities. By focusing on the perceptions of Indigenous parents and carers, this study does not pretend to document current child protection practices as observed by an impartial outsider. Interviews were conducted between March and December 2008. The semi-structured interviews averaged one hour.

In an Indigenous context, parenting responsibilities are assumed not only by parents but also by other family members in a child's kinship network such as siblings, aunts, uncles and grandparents. Other family members assume critical roles from a child protection context, roles such as disciplining and supervising children. On this basis, self-identified carers not just biological parents were included in the study. The criterion for inclusion was that the parent or carer had had direct experience with a child protection authority.

The sample comprised 26 biological parents and 19 carers, of whom 37 were female and 8 male. In total those interviewed were caring for approximately one hundred and forty-eight children. Their backgrounds were diverse. Almost half were in paid work, and while not 
directly asked about their qualification, a small number of interviewees referred to study, including post-graduate study, being undertaken. Twenty-two interviewees, almost half, volunteered information about their direct experience of former removal policies as part of the 'Stolen Generations'. A sample of biographies is as follows:

$\mathrm{Y}$ was a grandmother looking after 2 of her 4 grandchildren. Her son and daughter-in-law were a professional couple whose issues with alcohol and depression respectively resulted in the school notifying authorities and the children being removed. Despite her requests to authorities to allow her to care for all 4 of her grandchildren with whom she had a very close relationship, child protection authorities denied this without explanation.

S was a young mum, whose first experience of child protection services was when she attended the police station to report a domestic violence incident. Police made the notification to child protection authorities while she was at the station without her knowledge. She was subsequently informed that action was to commence to remove her baby daughter.

$\mathrm{H}$ was a young dad who had a past criminal history. He discounted himself as a potential carer, assuming authorities would not allow him to care for his young son who had been removed from his estranged partner. He was offered care of the child. His case was before the family law court.

In seven cases family law court involvement overlapped with child protection involvement.

Domestic violence, alcohol and drug use were mentioned in about one third of the interviews.

Of the 26 parents interviewed, 21 had had children removed from their care involuntarily.

For 12 of these parents, children had been returned. All but four of the 19 carers were related

to the children being cared for: 11 were grandparents. Two of the four non-related carers, while not Indigenous, were accepted by the children's parents and extended family and community as suitable and appropriate to provide care.

In order to find an adequate number of parents and self-identified carers to interview, a 'snowball' technique was used. Contact was made with local Indigenous Elders to discuss the study and to ascertain interest in and support for promoting the study through different 
Indigenous networks. Indigenous community-based organizations, Indigenous liaison officers in mainstream organizations and various other mainstream service providers were also contacted and briefed about the aims of the study. Posters, fliers, Indigenous email networks and Indigenous media promoting the study attracted a small number of participants. Most participants were enrolled in the study through 'word-of-mouth'. Extensive notes were taken at all interviews and then transcribed. Tape-recording was considered inappropriate, particularly as Elders who provided early advice to the researcher expressed concern that interviewees would feel inhibited to speak freely. Confidentiality and trust were major concerns for most parents and carers who had on-going involvement with child protection authorities. As the content of these interviews was anticipated as being potentially distressing for parents and carers, participants were invited to bring along a trusted companion to accompany them at interview if they so wished. Contact details for support organizations were also made available to research participants.

\section{Limitations of the Study}

All participants who came forward to be interviewed had experiences with child protection authorities. Clearly, for some parents and carers it was their first ever encounter with child protection services. For others, there had been a long history of involvement with authorities. This study may draw the criticism that it is 'biased' toward those with an unhappy history with authority. With no basis for comparison, it is difficult to say whether this is the case or not. But even if it is only 'one side of the story', the views of this segment of the population matter. If those interviewed for this study represent the more difficult child protection cases, understanding more fully their sources of grievance may provide insight into how such cases might be handled in a more effective manner. 


\section{Main Findings}

\section{(a) Historical threat of harm and child removal}

Approximately half of interviewees referred to the 'Stolen Generations' and historical encounters with authorities as part of their own family history and as part of Australia's Aboriginal history of intergenerational removal of children. Contemporary child protection authorities may or may not be surprised that they were perceived by a significant proportion of respondents as an extension of the historical authorities who were responsible for the coercive removal of children from Aboriginal families and communities (Bringing Them Home Report 1997; Rudd 2008):

$C P S^{11}$ are a threat to our freedom; we're fearful of CPS; the police take the adults away, welfare take the kids away. How do you gain respect for an authority which was responsible for Stolen Generations. (i/v 18)

They used to be the Aborigines Protection Board, then the Aboriginal Welfare Board and now DoCS. ${ }^{12}$ The attitudes are the same. ( $\left.i / v 20\right)$

CPS ... changes its name but it's the same beast. (i/v 36)

There's nothing good from them fellas [CP]). Every time they come they're making threats. [It's an] instinct in the Aboriginal family because of the old records and history. Not a very good history. It will never change. ( $i / v 38)$

For many of the Aboriginal parents and families interviewed, the history and experience of coercive child removal remained a real and on-going threat in the present day despite government intention for reparation and despite commitment to authorities' mission of keeping children protected from danger.

\footnotetext{
${ }^{11}$ Child Protection Services

${ }^{12}$ Department of Community Services
} 


\section{(b) Acceptance of the role of the State to keep children safe}

With historical encounters as they were, it was striking to find two thirds of interviewees directly referring to the need for child protection authorities to keep children safe and an expectation that this responsibility lies with government when all else fails:

When there is child abuse something has to be done, who else can intervene, intervention must come from the State. ( $i / v$ 32)

This is not to suggest that the remaining third rejected authority - simply that the interviewee did not raise this as an issue. Nor does this acceptance for child protection authorities suggest that those interviewed were willing to be subservient or that they agreed with the decisions made. Those interviewed were overwhelmingly resistant, but along with the resistance was acknowledgment that there was a place for child protection authorities - the issue was not to abolish case managers but rather replace them with better ones as illustrated below:

[I've got a] good caseworker now. I got rid of the last one - [she] used to come with her designer clothes, just out of school - lots of good [she did]. (i/v 27)

This person's criticism of the 'last one' is harsh, but there was no intention to discount the role that authority could play in improving outcomes for children more generally - the new worker was accepted, even praised. A similar point was made more dispassionately and in a less personalized way by a male parent:

CPS are needed in society, yes, just like the police, it's just the process that needs to change. (i/v 6)

On one hand this is a surprising finding given that the sample were, by and large, unhappy with how they had been treated at the hands of authorities, both historically and in the present. On the other hand, no-one was prepared to contest the idea that children deserved protection 
from abuse and that child protection authorities had a role to ensure that all children were safe.

\section{(c) Perceptions of the style of engagement of child protection regulators}

The formality of bureaucratic decision-making processes risks losing sight of the person and their feelings as "the rules" are applied to their case. Three major types of complaints were made by interviewees about how they were handled by authorities: (i) lack of respect, (ii) stigmatizing treatment, and (iii) poor understanding, empathy and compassion.

(i) Encounters lacking respect: Respectful treatment by any authority is considered as a basic starting point in dialogue or in building a working relationship, including when working with 'involuntary clients'. Respectful treatment is central to Tyler's notion of procedural justice (Tyler 1990). Instances of respectful child protection practice were identified in about one third of the interviews. Examples were given of workers, where 'some were and some weren't respectful' (i/v 2). Interviewees were quick to identify workers who 'had a bit of a laugh and a joke... friendly [who] didn't think you were lying... '(i/v 38).

While these positive encounters were welcomed and easily remembered by those interviewed, parents identified disrespectful treatment as a more common experience:

They come to the house with an attitude. They don't have a good attitude-talking down to you. (i/v 39)

[Son] got angry when the kids were taken. They showed him no respect and he showed them no respect. They threw the book at him because other children died. ${ }^{13}$ (i/v 20)

\footnotetext{
${ }^{13}$ Reference to death of Dean Shillingsworth in October 2007, a two year old whose body was found in a suitcase floating in a pond by local children. The boy had been dead for a week. In August 2009, the mother pleaded guilty to his murder. http://www.theaustralian.news.com.au/story/0,25197,25945992-2702,00.html
} 
I hate how they talk to you. They don't listen, they talk down to you. (i/v 42)

They treat me as if I'm stupid (i/v 23).

The pronounced need for and expectation of respect due to Elder status and cultural expectations was recognized by a number of those interviewed:

They have to have respect for us, our culture, be aware of our family values...they need to come and get advice from us. (i/v 18)

I feel they all judge me as a parent. I am an Indigenous girl-we have different ways of looking after our children - they don't know how we act. (i/v 11)

It's our cultural belief that when you're pregnant you don't have a male with you alone in a room without your own male there. Having a male caseworker made me feel unsafe and insecure. He [caseworker] wouldn't allow anyone else in the room. (i/v 26)

CPS should take the time with Indigenous people. Not many Indigenous people make contact because of the past, because of that history. CPS should open the door to close the gaps. $(i / v 40)$

A few parents were able to identify a time when their Aboriginal status was respected.

I feel the workers respect me, they understand me, my Indigenous culture. I feel they want me to succeed. (i/v9)

Mostly, however, effort was not made to communicate respect for culture:

Nothing about our Indigenous heritage was ever asked.(i/v 17)

(ii) Regulatory processes as stigmatizing: Stigmatization occurred in regulatory encounters

when parents and families interpreted child protection authorities as communicating unworthiness - unworthiness of the whole person, not just disapproval of a practice.

Importantly 33 of the 45 people interviewed held out little hope of ever gaining approval from 
child protection authorities. 'Bad or unfit parent' was the stigmatizing label that emerged from these 33 interviews:

The bottom line is that they see her as a bad parent (i/v 38, Grandmother)

This doesn't just happen to black people - if CPS consider you 'not worthy', they take the kid and claim you as an 'unfit parent'. (i/v 9)

Carers felt this stigmatizing label was extended to include them:

We're seen as part of the problem. (i/v 27)

Parents perceived that any efforts they made to 'reintegrate' - to be accepted as 'good

parents' were ignored by authorities:

I realize I stuffed up but I've made positive changes...I've made mistakes but don't punish me for the rest of my life...I was told 'if you get a job, do a parenting course, stay away from the ex(partner)...has any of it helped - nope. So many groups I've done..." (i/v 1$)$

Parents also reported a sense that their 'punishment' never ended:

You're always wondering when they're going to turn up - the phone callcontinuously going through your head. What about your kids, will they be harassedwhat about their kids.' (i/v 12)

Thirty-four interviewees perceived they had been given few or limited opportunities for reversing the authority's opinion of them:

CPS don't care. I used to tell them, say to them, 'come over, videotape me, sleep over - they're not even prepared to do that. Now I have a black mark against my name. $(i / v 23)$

CPS got reports and instead of helping me they took the kids...until 18. I wasn't given any options - no rehab. Maybe temporarily they could have taken the kids - but not to that extent, till 18. (i/v 25)

When does somebody get a chance... "my manager thinks you haven't done enough"..[The manager has] never met with me or the kids. (i/v 31) 
Age was mentioned a number of times as a discriminatory factor in how young parents were treated:

My son was taken at 6 weeks old...I just turned 16 when I had [my son]. I rang DoCS, went in for a meeting... I was given a tick list with a calendar of visits. They made allegations about me...they didn't need a reason - I had the same DoCS worker as worked with me as a child." (i/v 5)

Young mums don't get a chance. I feel like they still look at me like I've got drug and alcohol problems. (i/v 8)

Parents' Indigenous status was also identified by some parents as a reason for biased

treatment:

They just want to make us black people like white people. (i/v 11)

Aboriginal women like my daughter - I believe they get targeted. (i/v 39)

(iii) Regulatory processes as dehumanizing: Those interviewed deeply resented processes

that were seen as an abuse of power, as being dehumanizing because caseworkers would not listen, show empathy, understanding or compassion. The absence of an attempt to engage was considered unacceptable:

They [CPS] should talk it through. Not say 'we're going to do this and this is our job'. They talk about themselves, not listen to parents; [they just] listen to themselves, their job's inside their mind. They only understand what they have to do, not understand what the human being inside the parent wants. Do they have children of their own? Do they know how it feels? I bet they don't. It's like they've got no heart. They rub their heart out. (i/v 11)

I feel not heard, [you have] no voice with them [CPS]..you get shut down and don't have a voice if you disagree. All you can do is sit there and take it. (i/v 25)

The week my partner went to gaol, they're saying my house is a mess...that I don't know how to raise my kids. They object to my dog...I've organized three meetings with my other workers and CPS hasn't turned up.... [they] won't have a meeting to do a restoration plan. Ten minutes before we're supposed to be meeting they ring up and cancel or just don't show. (i/v 26)

They should work with the parents...they put us on show, putting us to shame, putting us on the spot. (i/v 28) 
Also regarded as unacceptable was legal language that robbed parents of their voice:

When we went to court...I couldn't understand a word she [psychologist] was saying or what was written. (i/v 18)

My first solicitor...gave me the wrong advice...I should never have been made to sign the paperwork - first solicitor just told me to sign the paperwork. (i/v 26)

Housing is a basic need for all children and families. In 16 cases housing was identified as an issue that contributed to decisions about care arrangements that did not necessarily take into account the best interest of the child but were a consequence of applying formal rules. In many of these cases the need for housing was linked to women wanting to leave domestic violence situations. When they left their family home, they had no housing, and therefore could not have custody of their children. They were then caught in a catch-22 situation. Parents spoke of not being eligible for government housing because they didn't have their children living with them (that is, children were removed):

I had to throw my housing in when I came here [detox centre] ... Housing wouldn't hold it. I'll have to apply for housing again. I put myself in rehab. There's a family program here - I could have brought my kids here - I was given no option to bring my kids here. I have to go back to court to get them back. Get some secure housing... (i/v 25)

One grandmother who was providing care for two of her four grandchildren had the following story when she tried to enlist the co-operation of child protection authorities in obtaining housing for the foster carer with whom the other two grandchildren had been placed:

I asked for their [CPS] help to get a transfer for the foster carer [who was agreeable to the move and it meant the grandchildren could all be closer together]. They [CPS] told me they've got no authority to go to another Department, 'it's outside the guidelines and that's not our job' they said. (i/v 20)

The capacity for child protection to exacerbate the difficulties people were having was significant. Parents and families referred to having to 'gather the debris' following child 
protection intervention. Encounters with authorities were routinely described in the following way by all except one interviewee:

They walk in and leave your life in pieces...turn your life upside down...they fight you in court then leave you and say 'go and see your psychiatrist.' ( $i / v 1)$

My whole life was wrecked. Had a great job, lost it. Felt I was treated like an animal. (i/v 13)

My life has been completely turned upside down. (i/v 29)

\section{(d) Perceptions of the purpose of the child protection authority}

Overall parents and carers felt confused about the goals of child protection intervention and why they were doing what they were doing. Confusion centered on the belief that authorities should be supportive and able to help parents keep their children: 'They're meant to keep families together, not to rip families apart' ( $i / v 25)$. Criticism of lack of clarity in the stated aims of child protection systems has been well documented in Australia (Allen Consulting Group Victorian Review 2003; Ford Review Western Australia 2007). Even the role of Indigenous Units within statutory child protection services was confusing for parents and carers. This section presents evidence of confusion and dissatisfaction about what child protection authorities were doing even though parents and carers were clear on their own needs and failings.

(i) Parents and families needing help: There were parents and carers among the interviewees who were quick to acknowledge they needed to do better at parenting:

We don't want to be druggos and drinkers. We want to be good for our children. (i/v 11)

I knew I was a good person. I knew I was a good mother. I had an open mind and I wanted to strive to improve. $(i / v 4)$ 
There's lots of parents who need help-might be on drugs, but want to be good parents. (i/v 14, Grandmother)

In two-thirds of the cases interviewed, parents and extended family members recognised gaps in care for children. Half of those recognizing gaps were parents. Parents either initiated contact or recognized that contact with authorities by another party was justified because of issues which may have compromised children's safety:

I called them in good faith, I needed help, I believed I was wise enough to recognise that I needed help. (i/v 3)

Why don't they help people who want to be a family, help them work together, work out their issues and be positive not negative about the family. (i/v 11)

Carers too looked to child protection authorities for support:

[The Department could ask] if you needed help with respite. Everyone needs time away from the kids, even your home kids. The kids are there because of problems, otherwise [they] wouldn't be there. (i/v 15, Grandmother)

(ii) A perception of little support: With one exception, those interviewed routinely reported

little direct help coming from child protection authorities:

I was offered services, but they didn't come through - lots of promises but no action. $(i / v 2)$

I have to think of my daughter too. There's no support for my daughter.... We have a vested interest in these kids, in our children [biological adult child with 'the problem']. We want to see them succeed and do well. You don't want to be a victim. ( $i / v$ 27, Grandmother speaking about her daughter)

Dads don't get any help. (i/v 35, Grandmother speaking about her son)

They say kinship care is best but they give us no support. If they listen to us - we know what we need-especially in the first few months, you need support. (i/v 27)

In three cases, interviewees expressed mixed feelings about the 'help' received:

It would have been good if they talked to me-offered to help ... they said I had to do it off my own bat....looking back I'm grateful for CPS intervening and people making 
the reports - I just don't like the way they dealt with it when the reports were made. (i/v 25)

When I first took on the kids, I'm a grandmother, working...you'd ask for help and some of the time it was fine and other times you got nothing. (i/v 15$)$

I've worked over the years with CPS [through work] and they're not about taking kids from families, they're about helping families to stay together except in extreme cases where they take the kids. [But]I came to loggerheads with the Department when I went to CPS to see what they could do to help me [with grandchildren]. They failed me. ( $i / v$ 40)

In some cases hopes for support were very high:

They should try and help you get your kids back. They should say 'do you need help with anything, we'll take you shopping'. If they take the kids, instead of giving you a timeframe, they should say we have to give you this support, this is what we can do. I didn't get the care. (i/v 8)

By the same token, there were some positive stories of help, in this case without the child protection authority being involved in an investigation:

CPS helped us out immensely, got us on the housing waiting list, ...they advocated on our behalf to get a house...gave us hampers, toys and tucker, linked us in with support. $(i / v 21)$

There seemed differences among interviewees in what it meant to be helped by child protection authorities. Part of the problem seemed to be recognition of the need for help along with resentment that child protection authorities controlled resources and families' futures.

Our futures are in the palm of these people's hands and they don't know us. (i/v 25) CPS can change your life with a stroke of a pen. ( $i / v 42)$

Indigenous Units within statutory child protection services have been used in an attempt to bridge the gap between government and Indigenous communities. Their capacity to provide support, however was regarded as limited.

We want someone who can work for the community, the parents....It's a little unit and has no power to do anything. They can't question the work of the caseworkers. The 
Ministers say 'we're not racist because we are taking care of Indigenous because we have a Unit." (i/v 14, Grandmother)

I asked for the Aboriginal Liaison worker, I was told 'no, she's related to you.' I told them, 'she's related to the whole [area].' (i/v 23)

(iii) Absence of transparency and information: Parents and carers felt that the decisions made by authorities were generally not explained. Whether actions related to the removal of children, reunification, contact arrangements, court processes, or information about whether children were attending school or receiving medical attention, authorities often cited confidentiality and privacy as reasons for not sharing information. Parents and grandparents were left uninformed:

Before there was any communication with us, CPS took [the children] and placed them interstate with my Mum. (i/v 3)

CPS here don't want me to know anything. I am a 'disgruntled mother'. That's what they told me.(i/v 23)

I'm seeking legal advice - they're [CPS] not telling me what's going on. (i/v 39, Mother)

They haven't told me what I need to do to get my kids back. (i/v 31)

I have to look after the kids and be the caseworker for the mother...They have not told her what she needs to do in order to get the children back (i/v 41, Carer about her niece)

The manner in which children were removed generated high levels of anxiety and powerlessness - higher than was necessary. Surprise visits and removals are part of child protection processes and will always generate distress. But this should not be accepted as the norm for everyday practice. It was unclear to some parents when child protection authorities considered it acceptable to have the support of their family and when it was not. Often parents and families were left with little information about what would happen to the children. 
Particularly confusing for parents and families were situations where one child or two children were removed while others were left in the care of parents:

We're just as much in the dark [now as we were two weeks ago]. We're not allowed any contact with her [grand-daughter]. They got us to pack an overnight bag and took her. The youngest is still in our care. (i/v 19, Grandmother)

We used to have [grandson] Monday, Wednesday and Friday. They cut my visits only to Monday. I see him every Monday [for three hours]. I've got my other granddaughter here - she has sleep overs here (i/v 10, Grandmother)

Interviewees frequently referred to conflicting messages from authorities. This occurred across caseworkers, across offices (especially if there were cross-border issues) and across professionals - for example, psychologists and lawyers were reported to present information favourable to the parents that was then ignored by child protection officers. It made little sense to people, one concluding that it was a case of selective pickings of what supports their position' (i/v l).

\section{(e) Perceptions of the blind spots of child protection regulators}

The acceptance of rules and enforcement by authority rests on a shared understanding of what is desirable conduct. The question of whether child protection workers and parents/carers have a similar understanding of appropriate standards of care is beyond the scope of this research. A preliminary question that can be addressed is whether there is evidence from these data of diverging values, or rather, perceptions by Indigenous parents and carers that the authorities have lost touch with mainstream beliefs and expectations in their quest to keep children safe. These are referred to as blindspots of the authority, fundamental aspects of child protection practice that jar with the community's understanding of how authorities should be operating. 
Interviewees in this research valued what most of us value, namely, relational bonds of family. Interviewees believed that these relational bonds should be understood by the authority even if they saw them as damaging in some way for the child. They perceived little evidence that authority understood the positive side of relational bonds. Moreover, parents questioned whether what the child protection authority was doing for children was desirable, that is, whether workers were acting in accord with socially shared values, norms and beliefs about what was best for children. Four blind spots of child protection authorities were identified through the interviews: (i) failure by authorities to acknowledge familial bonds and relationships between children and their families; (ii) failure by authorities to identify and harness existing caring partnerships with others involved with the child or family identified as being 'at risk'; (iii) failure by authorities to acknowledge the limitations and quality of the care they provided to children 'in care', and (iv) failure to adequately deal with vexatious complaints.

(i) A blind spot over child-parent and family attachments: Defined broadly, attachment is the long lasting emotional bond typically developed by infants towards their principal caregivers and integral to a child's development (Bowlby 1969). In this study those interviewed believed that attachments to family more broadly were important. What was seen as authorities' dismissiveness of the bonds which children have not only to parents but also to other family members generated distress and anger towards child protection agencies:

[CPS] say "there's no bond or attachment between you and your child, the bond is with the carer." ... I was given a DVD of [child] at his first day at school - he was bawling his eyes out - I just wanted to be there and comfort him. CPS said they couldn't see how it was beneficial for me to be there for him at his first day at school. Their idea of my contribution was to get him a drink bottle and a lunch box. ( $i / v 1)$ 
Carers often recognized the attachment between the children they were caring for and the children's attachment to their biological parents and siblings, even if the authorities did not:

We've asked for counseling for the older one - her heart's broken about her Mum. She's very vulnerable but DoCS won't organize counseling. We're really worried about her. She's desperate to be with her mother and to have a relationship with her. (i/v 16 carer)

My grandson loves his parents. He just cries after he sees them. [Caseworker] doesn't see those children crying and cuddling each other when they have to leave - the escort person sees it, they just cling to each other. I have a recliner chair, they sit there with their arms around each other. I've never known a caseworker or social worker to be here when the children are with each other. (i/v 20)

Carers spoke of their own efforts to provide children in their care with opportunities for contact with birth parents. This included contacts that were

secretly arranged outside the department. It was really important that this father who had shown an interest have some contact. (i/v 44)

One young man, having gone missing from the refuge was seen at KFC with his Mum - that's where he'd gone. To see Mum. (i/v 33)

In twelve cases, children had returned to their parents' care. One story of reunification captured the tension between enduring parent-child bonds and persisting parental uncertainty about how to be a good mother:

I think my story is generic. The 3 older boys started coming back home.... The kids were $15 \& 16$. One day a car pulls up and brings them back. The foster family moved and I had no warning. .... They had 1 or 2 bags of clothing each. I had a few beds -I felt the Department gave me about 10\% support when they came home. No family support, no mentor, I never really knew what it was like to be a parent. [Son] calls his Auntie, 'Mum,' and he calls me by my name.... I still wonder whether I have the ability to be a good parent. I will never know....5 children. I really doubt my capabilities in that regard. Even today, got my life together, no drugs or alcohol but [I] still doubt my own ability to be a mother. My kids text message me, 'we're so proud of you.' I kept it for 18 months that text message. I found myself regretting the lost years - glad my children are old enough to speak up for themselves ( $i / v 3)$ 
(ii) A blindspot over caring partnerships: The possibility that Indigenous parents, families and carers were positively motivated towards keeping children safe was not recognized by authorities, at least not in the eyes of parents and grandparents. Some mentioned the possibility of 'partnering' with authorities, even bringing in 'third party regulators' to keep children safe:

Instead of taking the kids, put the carer in the house or take the family and put them in a house with a carer. (i/v 2)

His Mum \& Dad can't pull it together but that's not to say that someone in the Indigenous community can't. ( $i / v 45)$

The view of most interviewees, however, was that authorities saw no benefit in partnering between parents and carers, or parents and the informal care network:

Carers and parents are kept separate. [They're] not meant to interact... [you] should be able to go out to a neutral place so that the kids can see the carers and parents together-for parents to see the carers. We know nothing about the carers and we want to know about the carers. (i/v 1$)$

...I can see them taking [grandson] from me. I can't do it again. If they had contacted me first we could have all worked together. No-one has worked together as a whole unit - not supporting them [son and his partner] being a family. They [CPS] want the family separate. My son is a good person, just had a fucked up life. (i/v 13)

We offered to sort it out ourselves, between the families, sit down, have a cup of tea, and they said, 'no, we're the workers.' (i/v 14, Grandmother)

Grandparents comprised 11 of the 19 carers. Eight of the 11 had made contact with authorities to share their concern for a child or young person before that young person was placed in their care. These 'informal regulators' simultaneously believed that contact with authorities would enable some form of 'working together', facilitate access to support services and achieve the mutually shared goal of keeping children safe.

One might think that in such circumstances, child protection workers were wary of being embroiled in family tensions across generations. Interviewees openly admitted disagreements 
between parents and grandparents over care, but simultaneously acknowledged bonds that appeared to transcend differences - at least after the disagreement had passed.

Mum put welfare onto me...Mum tried to make a difference...my relationship with my Mum is good. I hated her because she done it to me [called the welfare] ...I saw what I done wrong. Mum blames herself - she stresses out and comes down [to help out] but we can't live together. (i/v 8$)$

In many cases, respectful interdependency across generations was evident. One father who was open about his own failings as a parent was full of praise for the role his mother played in his life:

My Mum has a moral compass - if it doesn't point the right way, she'll take the kids! Mum's a safety net for her sons. (i/v 6)

The issue of co-partnerships involving formal and informal care networks is one that received a sympathetic hearing from Indigenous respondents, even though they interpreted the authorities as lacking interest.

(iii) A blindspot over out-of-home care: Interviewees spoke of negative outcomes for children and young people not because child protection authorities wanted to harm children but because things got 'bogged down.' Those interviewed reported having to consistently advocate for educational, health and other services to be provided to their children in out-ofhome care. Highly formalised, process oriented regulation meant that parents, grandparents and carers had to seek permission from authorities before undertaking what would normally be understood as appropriate action.

When I took my grandson to the doctor the Department said 'you took him to the Doctor's without our permission. You have no right to take him to the Doctor.' [When I challenged them] I was told 'lose your attitude. Don't you make demands on me' by the caseworker. (i/v 27)

The Department didn't enrol her in school and we were desperate. To have anything work for the children you have to organize it yourself. Even without permission. (i/v 16, Carer) 
Parents felt that their children's educational outcomes were poorer due to movement associated with multiple placements or simply because young people were not attending school while in the care of authorities:

[One son, aged 9] missed a year of school in [foster care] - he went two times a week to school for an hour a day...[Other son, aged 10] had no schooling during this time. ( $i / v$ 28, Parent, referring to three separate foster placements and locations )

Child protection stuffed 12 months of my children's education. The kids went to bed with one set of carers and woke up with other carers... [There was] a substantiated case of abuse while in care. [They have had] behavioural problems since being in care. (i/v 2)

Parents and carers saw the system as inflicting its own harm on children:

CPS let the young teenagers go into hostels. They went to ruin since being under CPS. I haven't seen them so bad, They've been in more danger since they've been under CPS. [I'm] writing a letter to the Ombudsman. They're in juvenile detention now - got into trouble with ice and stuff. (i/v 7)

The Department lets everyone down, especially kids. (i/v 14)

2/3 of the kids in juvenile justice are Indigenous kids. No Indigenous worker - All those kids have had child protection involvement. [The path is child protection to juvenile justice to adult corrections] - that's the training, I'd bet my life on it. (i/v 13)

(iv) A blind spot over vexatious complaints: Interviewees were aware of vexatious complaints being made to authorities:

Some families use child protection as a threat against other families - if there's fighting between families for example. (i/v 16)

More alarming were five cases in which young people had made accusations against their parents or carers. The complaints were subsequently withdrawn, but not before the children had spent time in out-of-home care. Interpreting these data is problematic without talking to 
the children concerned, and preferably alone. One young man, however, who attended the research interview with his step-Dad had the following to say:

Any kid can lie. It was good at first - they (CPS) gave me anything, took me places, they try to get you away from your parents. [But] I saw the problems I made for (my step-Dad) .. no-one told me I got everyone in so much trouble. When you're a kid it's great when people do what you want them to do. (i/v 30)

One interviewee, an uncle who also worked in the community as a professional worker and cared for four of his nephews recalled how two of his nephews

were playing us [CPS and me] off against each other - they know they can go over the top of you - this is what they do if you don't give them what they want. ( $i / v$ 37)

Interestingly, those interviewed were all too aware of the first step toward resolving this and other similar problems - conversation:

The biggest and easiest way that things could be different - talk to the families straight away - when a child says, makes an allegation, talk with me, 'Are you x's mother/grandmother, what's your role, what can you tell us? (i/v 13)

\section{Discussion}

This paper sought to uncover some of the reasons why it might be difficult to reset the relationship between Indigenous Australians and government child protection authorities. The trigger for the study was the disproportionately high number of Indigenous children under care and protection orders. The seriousness of the problem is exacerbated by a history of the forced removal of Aboriginal children from their families, a history that was not acknowledged until the National Apology was made to the 'Stolen Generations' on 13 February 2008. The data presented in this paper raise two questions: 'Have our practices 
changed to match the sincerity of the National Apology?,' and 'What are the new regulatory approaches that might deepen learning from the mistakes of the past?' 14

For purposes of analysis and presentation, the data were organized around three themes: (a) How were parents and carers treated by the child protections authorities? (b) What kind of understanding did parents and carers have of the regulatory authority's purpose and expectations? and (c) What did parents and carers regard as the blind spots of the child protection authorities?

\section{Treatment: Does it matter?}

Parents and carers could recall child protection officers who had treated them decently and who had developed a good rapport with them. There was a predominance of grievance, however. Grievance around treatment (and around low transparency and information discussed in the next section) indicated that interviewees were experiencing a lack of procedural justice (Tyler 1990). Procedural justice elicits cooperation (Tyler 1990). Authorities may not be able to give people the outcomes they want - their desired outcome may be against the law or harmful to someone else, but they can show respect through abiding by due process and giving people a fair hearing. Tyler (2008) has produced evidence to show that procedural justice does more than give authority legitimacy: It actually leads to shared moral standards which, in turn, lead to cooperation and compliance with the law.

\footnotetext{
${ }^{14}$ In September 2009 in the town of Lightening Ridge, New South Wales, the Department of Community Services removed children - by its count 30 of them, although that's disputed by local women, who put the number at 41 - because they were at "serious risk" of harm. http://www.theaustralian.news.com.au/story/0,25197,26045824-5013945,00.html and Koori Mail, 9 September 2009, Fear and Despair In Lightning Ridge p. 5)
} 
Feeling respected and valued as a parent and/or grandparent did not accompany encounters with authorities for most parents and carers interviewed. First, parents and carers made frequent reference to uncaring practices to the point of feeling dehumanized by child protection officers. Such practices arguably were the result of rigidity and inflexibility in the ways in which child protection authorities performed their duties - unwillingness to coordinate with housing authorities, hiding behind paper work, and using their formal (and narrowly conceived) role to disconnect from a broad range of needs.

A second element in how parents and carers described their treatment by child protection officers was stigmatization. The overarching perception of those interviewed was that authorities held out little hope that satisfactory care could be provided for children by their biological parents - an attitude of once a bad parent always a bad parent seemed to prevail. The problem was regarded as being particularly pronounced with young mums. There was also a view among some that Aboriginality was equated with unacceptable parenting.

The third element that emerged in relation to treatment was the more overarching issue of disrespect. Those from the child protection authority were seen as having an attitude of condescension, of looking down on parents and families, and of lacking appreciation of Aboriginal culture and different norms for raising children. In reports of both stigmatization and disrespect, there were overtones of racial discrimination, though it is important to emphasize that some interviewees made a point of discounting this interpretation.

Perceptions of treatment that was dehumanizing, stigmatizing and disrespectful suggest problems of over-bureaucratization and perhaps even prejudice; or they may reflect an uncaring and alienated workforce that is fatigued by overly demanding clients and impossible 
workloads (Fleming and Grabosky 2009). While not refuting either interpretation, data collected recently from government child protection workers suggest that they do not see their own actions in such a way and that such actions would be antithetical to their professional values (McArthur and Conroy 2009). There remains a question of how these different world views, one from government workers, the other from a self selected sample of Indigenous Australians can be reconciled.

One possibility is that the social and cultural distance between professionals and government on the one hand and Indigenous families on the other has become so great that these groups are unable to connect in a meaningful and respectful way. Perhaps child protection officers genuinely can't see any way of achieving better outcomes through building strategic relationships with those being regulated, even though success has been achieved in other fields (see Heimer \& Staffen 1995 for an account of parental support in neo-natal care units). In part the fault may lie not so much with individual professionals, but rather with a bureaucratic structure that has evolved in such a way that it cannot meet the needs that exist among Indigenous groups. It should never be assumed that as institutions evolve they do so in ways that are inclusive of the demands of all segments of the population - they may evolve to meet one set of political demands, leaving a swag of the population behind. Exclusion then leads to this population disengaging from the authority's domain of influence, sowing seeds for further and more widespread defiance and noncompliance that can swamp the enforcement capacities of the authority (Pontell 1978; Kleiman 1993; Kennedy 1997).

\section{Purpose: Is the relationship between child protection authorities and parents destined for disappointment and failure?}


Data on how parents and carers understood the purpose of child protection authorities were categorized in terms of needing help, support, and transparency in child protection decisions.

Two thirds of those interviewed reported needing help, half of these were parents. While some were inclined to shun authorities and there was some game playing going on, an alternative message prevailed. The interviews reflected sorrow, acknowledgment of inadequacies in parenting, and struggle to hold families together - particularly by grandparents. Grandparents were clearly concerned to do what they could to provide a better life for their grandchildren, but also their biological children who, to put it in the words of one interviewee, 'had a fucked up life'. Grandparents were not walking away from their responsibilities and at times seemed to be managing the situation, including managing the government departments that they believed should have been providing more practical and relevant support.

While not discounting the complexity of these situations, the perceptions of parents and carers that the child protection authorities were unable to be responsive, not merely to the needs of families, but more importantly to the efforts of families to build their capacity to care is a disturbing finding. An important function of regulatory authorities - and one that is known to improve their effectiveness in eliciting future compliance, is praise (J. Braithwaite 2002; Makkai, T. \& Braithwaite, J. 1993a). Praise by an authority strengthens both willingness to meet social expectations and belief in self that one is capable of doing what is required, in this case good parenting. Efficacy builds capacity and compliance (Jenkins 1997). The latter emerged as a problem in some interviews. Genuine self-doubt was expressed about capacity to be a good parent. 
Improving the behaviour of parents, a much needed objective to relieve pressure on the child protection system, requires parents to be able to see a pathway to a desired outcome - desired both by themselves and society. We may be able to please an authority by thoughtlessly copying others - we capitulate to authority without really knowing or caring why (Braithwaite 2009). This form of compliance is not conducive to becoming a good parent. The behavioural change desired requires commitment to being a good parent and having authority share our understanding of what this means and how we might get there. When we trust the authority to share our understanding, we know how we should change. Armed with this knowledge, the next step is to try - we cooperate.

None of this is possible when authorities fail to make information available on decisions and the thinking behind these decisions. For parents and carers, there was not only lack of transparency but also lack of meaning. Those interviewed complained of changes in care arrangements with little warning and no explanation. It did not make sense to them why they had some children taken while others remained in their care. Such complaints came from both carers and parents.

\section{Blind spots: Should parents and carers overlook them?}

Blind spots reflected issues on which there was risk of shared values of Indigenous carers/parents and child protection authorities breaking down. Blind spots of three types were identified by parents and carers: vexatious complaints, failure to acknowledge parent-child attachment, and lack of willingness to enter into co-partnering arrangements with informal networks. All government regulatory bodies have blind spots. To find vexatious complaints slipping through the net is not unusual, though sad when the effects of this game playing hurt 
families and the children who initiated them - an additional minus on top of the resources wasted in processing such cases.

Far more serious blind spots are parents and carers believing that child protection authorities are not aware of the bonds that exist between parents and children and are not interested in co-partnering with them in care arrangements. The public administration literature in copartnering is burgeoning (Bryson, Crosby \& Stone 2006; Boin \& t'Hart 2008). This makes the perceptions of carers and parents that they are being rebuffed even more damaging for future relationships. From the narratives of interviewees, one might infer that most shared the belief that child protection authorities didn't trust 'informal' care networks (even though such networks incorporate formal kinship obligations) (Stanley, Tomison \& Pocock 2003; Morphy 2008; Schwab 1997).

\section{Conclusion - Can responsive regulation offer anything?}

The National Apology called for the need to lay claim to 'a future where we embrace the possibility of new solutions to enduring problems where old approaches have failed. ${ }^{15}$ The data presented in this paper confirm that new models of child protection are long overdue. At the same time, it is difficult to see any model being accepted or being effective unless it is grounded in the experiences, observations and hopes of a broader cross-section of Indigenous Australians than has been interviewed here. It cannot be said in strong enough terms that dialogue is greatly overdue between government and Indigenous families and the nongovernment organizations that support them.

\footnotetext{
${ }^{15} \mathrm{http}: / /$ www.pm.gov.au/node/5952
} 
Any discussion of the applicability of responsive regulation must be framed in terms of empowering Aboriginal parents and families, while at the same time acknowledging government responsibility to remove children at risk. One approach to avoiding an impasse in dialogue over competing objectives of empowerment and removal of children is to apply principles of restorative justice and responsive regulation (J. Braithwaite 2002; J. Braithwaite 2004 describes how these principles are used for children exiting state care).

The central idea of restorative justice is to talk through the harm, and use the strengths of individuals in the group, including the perpetrator of the harm, to make amends. The approach does not walk away or hide hurts - be they abuse of a child, stigmatization of parents, or humiliation of family. All these harms can be addressed and with the cooperation of those in the restorative justice circle, a degree of restoration can take place through acknowledgment and commitment to an action plan for a better future.

Invited to the restorative justice circle or conference are children at risk and their parents or guardians, those concerned for and supportive of the child and those who are concerned for the parents or guardian (Braithwaite 2003). They are brought together with the child protection workers who have been involved and anyone who is in a position to become part of a care network for the family. With the guidance of a facilitator, concerns about a child's well-being are aired. The reason that everyone is there is to acknowledge concerns and make sure a plan is in place and has the explicit commitment of all to prevent future harm. The circle explores sources of support for child and parent. Help with a child's reading and homework might come from one person, playing football one afternoon a week may come from another. The commitment plan may also involve grandparents or other relatives volunteering to be there for a child when a parent is not coping or not available. The issue of 
giving temporary custody of that child to a grandparent might be discussed if the group was of the view that to not do so endangered the child. Options would be considered for how parents might improve their parenting skills and coping capacities. Someone might offer to live with the parent and share care until capacities improved.

It is important to recognize that the reasons for poor parenting may be illegitimate (drug abuse) or legitimate (paid work) - it does not matter for the purposes of deciding on an action plan to protect the child. ${ }^{16}$ The important thing is that the parent or guardian commits to calling in help before a problem arises, the priority being safeguarding the well-being of the child.

In theory, a restorative justice circle can be convened at the request of families without involvement of child protection authorities if there is no evidence of child abuse or neglect that is, if the law has not been broken. This is an important point for authorities always wary of involvement in resource intensive activity. A restorative circle can build support for Indigenous children and parents and prevent escalation of poor parenting to the point where it is identifiable as abuse and neglect. That said, when the law has been broken - when there is evidence that a child has been neglected or abused, the starting point also should be a restorative justice circle or conference. Court proceedings inadvertently switch the focus to the parent, and when the story captures the media attention, the switch is complete with preoccupation with stripping that parent of rights and privileges because of what she/he has done. A restorative justice approach keeps the focus on restoring well-being to the child,

\footnotetext{
${ }^{16}$ This is no different from current practice where children are removed from domestic violence situations even though their attachment to their mother is strong and positive. Children are removed with no implication that the mother is to blame - the reason is simply that she is unable to protect the children.
} 
giving everyone a chance to agree that things can be done to give the child a better future, and that everyone in the circle can contribute in a constructive way to making that future a reality.

Central to the restorative process - regardless of the seriousness of the problem, is empowerment of the Indigenous family and its support network. Empowerment is a forerunner of parents and families accepting responsibility. Equally important is a clearly articulated and agreed plan to ensure the child's safety - who will do what and when will it be done. The command and control imperative of some regulators to tell people what must be done takes a backseat to listening and understanding the family's problems and seeing what their own solution might be to ensuring the safety of the child. At the level of restorative conferencing, the child protection authorities would be on a par with other participants - they would not dominate or dictate the agenda, although they would be expected to meet their responsibilities of clarifying standards and insisting that they be met.

If the restorative justice space fails to provide a net of support around the child and parents, a responsive regulatory approach would ratchet up the authority's intrusiveness. Responsive regulation recognizes the multiple levers that can act on individuals to ensure they meet regulatory standards. The central idea is that authorities use the minimum force required within the law to elicit compliance. If problems are corrected on the strength of asking some critical questions of the parents, this is a desirable outcome. If parents' actions remain cause for concern, the pressure to comply exerted by the authority will increase and will continue to escalate until compliance is achieved. An important feature of a responsive regulatory approach is that the incremental step of intrusiveness from the regulator's perspective is perceived similarly as an incremental step in pressure to comply by those being regulated, in this case, Indigenous parents and families. 
One way in which responsive regulation and restorative justice can work together involves non-government agencies. Third parties like non-government agencies might be asked to increase their involvement. A third party non-government agency for instance might be asked to increase its involvement in managing the case and others may be required to work more intensively with the family. If the child was in danger, the child might be temporarily removed. Ideally this would be done with the permission of the parents. The restorative conference would have set out a plan for ensuring the child's safety and when the plan proved unsustainable, parents would understand that the child would be safer in another's custody until a new plan could be worked out and implemented. Another restorative justice conference of the care network would be called to revise or strengthen earlier decisions.

If progress toward creating a safe home for the child could not be made through the help of an agency, deterrent measures through the court system might be initiated. The court would determine the nature of the contact between parent and child. If all else failed, the State would assume custody of the child. Again, restorative justice conferencing would be used to discuss the problem and implications. This time it would be a more formal gathering presumably given the involvement of the court in the case. These graduated steps of coerciveness would not be a surprise to any participants in the restorative justice circles. The important feature of this process is that it commits to working with parents and families in a manner which empowers, values their point of view and seeks to persuade and encourage change in a respectful and collaborative manner. Should this process breakdown, the authority ratchets up its control and assumes greater decision-making power - an outcome foreshadowed, expected and agreed to as the appropriate course of action at the outset. John Braithwaite contrasts this process with what happens all too often in criminal justice: 
"In ... [western justice] systems, as a result of overload, it is the offenders who wear the system down rather than the reverse. The enforcement response is to hang back on confronting lawbreaking in a credible way early on, wait until really serious cases land in your lap, and then impose through the courts the harsh punishments that the media and a frustrated public demand in egregious cases. When the young offender finally ends up in jail, she is often genuinely shocked - after years of getting away with all manner of infractions ..." (J. Braithwaite 2002, p.35)

It is unsettling for some that responsive regulation starts from the premise that authorities coerce to keep us and others safe. Coercion, however, is not open-ended, nor should it ever be non-contestable. Exercising coercive measures always must be within the bounds of the law. A restorative justice/responsive regulation context has the additional feature that those being regulated have been involved in the process of deciding what actions should be taken by a regulatory authority when there is concern about the safety of children. Moreover, the overarching principle is that if people take steps to regulate themselves to prevent perpetration of further harm, authorities should not waste their limited resources to force some formal (and often ritualistic) form of compliance. In a responsive regulatory approach, the authority says 'I can and I will coerce compliance here, but it is better for everyone if you take responsibility for correcting this situation yourself'. It is only if agreements are not adhered to, that the authority ratchets up its intervention, first through deterrence and as a last resort through incapacitation. At this highest level of the regulatory pyramid, children are permanently removed from contact with their parents.

Helping parents become good parents has long-term benefits for a society, and benefits that extend beyond the family - investing in parenting programs is much like investing in education. Given that most parents are motivated to look out for their child, harnessing the caring response within parents and families should not be too difficult. It is worth noting, however, that parents who engage positively in ensuring a safe future for their children may 
not choose to commit to being their child's primary guardian. They may elect to give up their parental rights permanently - or temporarily. This is not necessarily a bad outcome. Through restorative processes, a journey of transition in parenting occurs, co-parenting may even prove a viable option. Undoubtedly the journey will be difficult for families, full of fear, sorrow and shame. But on offer through a restorative justice/responsive regulatory approach are the benefits of honesty, genuine and useful support, and a shared understanding of circumstances. Such benefits seem to be sadly lacking for the Indigenous families interviewed in this study, and historically for generations of Indigenous Australians. 


\section{References}

Allen Consulting Group (2003) 'Protecting Children: The Child Protection Outcomes

Project:' Final Report for the Victorian Department of Human Services, Melbourne.

Australian Bureau of Statistics (2006) Experimental Estimates of Aboriginal and Torres Strait Islander Australians, Cat. no. 3238.0.55.001, ABS, Canberra.

Australian Institute of Health and Welfare (2009) Child protection Australia 2007-08. Child welfare series no. 45 Cat. no. CWS 33. Canberra.

Australian Institute of Health and Welfare (2009) Indigenous Housing Needs 2009: a multimeasure needs model, Cat. No. HOU 214, Canberra.

Baldry, E., Green, S., and Thorpe, K., (2006) 'Urban Australian Aboriginal peoples’ experience of human services', International Social Work, 49(3), 364-375.

Boin, A and t'Hart, P. (2008) 'Public Leadership in Times of Crisis: Mission Impossible', in Boin, A. (ed) Crisis Management Vol. 3. London, Sage, pp. 1-15.

Bowlby, J. (1969) Attachment \& Loss, Vol.1._London, Hogarth Press and The Institute of Psycho-Analysis, Basic Books, New York.

Braithwaite, J. (2002) Restorative justice and responsive regulation, New York, Oxford University Press. 
Braithwaite, V. (2003) “Tax System Integrity and Compliance: The Democratic Management of the Tax System" in Braithwaite, V. (ed) Taxing Democracy. Understanding Tax Avoidance and Evasion. Ashgate, England, 271-289.

Braithwaite, J. (2004) "Emancipation and Hope" in Braithwaite, V. (ed) Hope, Power, and Governance. The Annals of the American Academy of Political and Social Science, 592, 79-93

Braithwaite, V. (2009) Defiance in Taxation and Governance: Resisting and Dismissing Authority in a Democracy, Surrey, UK, Edward Elgar.

Bryson, J.M., Crosby, B.C. and Middleton Stone, M. (2006) 'The Design and Implementation of cross-sector collaborations: Propositions from the literature.' Public Administration Review, December.

Burford, G. and Adams, P. (2004) 'Restorative justice, responsive regulation and social work', Journal of Sociology and Social Welfare, 31(1), 7-26.

Clayfield, M. (writer). (2009) 'Sydney mother admits killing son, dumping body in lake.' The Australian. Retrieved August, 3, 2009, from http://www.theaustralian.news.com.au/story/0,25197,25945992-2702,00.html

Cunneen, C. and Libesman, T. (2000) Postcolonial trauma: the contemporary removal of Indigenous children and young people from their families in Australia, Australian Journal of Social Issues, 35(2), 99-115. 
Fleming, J. and Grabosky, P. (2009) 'Managing the Demand for Police Services, or How to Control an Insatiable Appetite', Policing. A Journal of Policy and Practice, 3(3), 281-291.

Ford, P. (2007) Review of the Department for Community Development, Final Report, Government of Western Australia, Perth.

Haebich, A. (2000) Broken Circles: Fragmenting Indigenous Families 1800-2000, Fremantle, Fremantle Arts Centre Press.

Heimer, C. and Staffen, L. (1995) “Interdependence and Reintegrative Social Control: Labelling and Reforming 'Inappropriate' Parents in Neonatal Intensive Care Units.” American Sociological Review, 60, 635-54.

Hope, A. (2008) Coroners Report into 22 Deaths in the Kimberley. Western Australia.

Human Rights \& Equal Opportunity Commission (1997) Bringing Them Home. Report of the


Their Families, Sydney.

Jenkins, A. (1994) 'The role of managerial self-efficacy in corporate compliance', Law and Human Behaviour, 18, 71-88.

Kennedy, D. M. (1997) 'Pulling Levers: Chronic Offenders, High-Crime Settings and a Theory of Prevention.' Valparaiso University Law Review, 31, 449-85. 
Kleiman, M. (1993) 'Enforcement Swamping: A Positive-feedback Mechanism in Rates of Illicit Activity', Mathematical Computer Modeling, 17, 65-75.

McArthur, M. and Conroy, S. (2009) 'Values and child welfare practice', Presentation to Rosegarden seminar series, Australian Catholic University, Canberra, August 24.

Makkai, T. and Braithwaite, J. (1993a) 'Praise, Pride and Corporate Compliance', International Journal of the Sociology of Law, 21, 73-91.

Manne, R. (2006) The Stolen Generations: A Documentary Collection. Brisbane, ANTaR Qld Association Inc.

Morphy, F. (2008) 'Invisible to the state: Kinship and the Yolngu moral order', Centre for Aboriginal Economic Policy Research Seminar, Canberra, October 29.

Mullighan Report (2008) Allegations of Sexual Abuse and Death from Criminal Conduct, Commission of Inquiry into Children in State Care, Adelaide, South Australian Government.

Overington, C. and Hohenboken, A. (writers) (2009) 'Stolen regeneration.' The Australian. Retrieved September 21, 2009, from

http://www.theaustralian.news.com.au/story/0,25197,26045824-5013945,00.html

Pontell, H. (1978) ‘Deterrence: Theory versus Practice.” Criminology, 16, 3-22. 
Rintoul, S. (Writer). (2008). 'Praise for Rudd on choice of wording.' The Australian.

Retrieved September, 21, 2009 from

http://www.theaustralian.news.com.au/story/0,25197,23205327-5013172,00.html

Rudd, K. (2008). 'Apology to Australia's Indigenous Peoples', House of Representatives,

Parliament House, Canberra. 13 February. Retrieved September 21, 2009, from

http://www.pm.gov.au/node/5952

Rudd, K. (2009) 'Anniversary of Apology to the Stolen Generations', Media release,

Parliament House, Canberra, 13 February. Retrieved September 21, 2009 from

http://www.pm.gov.au/node/5307

Schwab, J. (1995) 'The Calculus of Reciprocity. Principles and Implications of Aboriginal

Sharing', Discussion Paper 100, Centre for Aboriginal Economic Policy Research, Canberra.

SCRGSP (Steering Committee for the Review of Government Service Provision) 2009, Report on Government Services 2009, Productivity Commission, Canberra.

SCRGSP (Steering Committee for the Review of Government Service Provision) 2009, Overcoming Indigenous Disadvantage: Key Indicators 2009, Productivity Commission, Canberra.

Strohfeldt, M. (Writer). (2009) 'Fear and Despair in Lighting Ridge.' Koori Mail, 9 September 2009, p.5. 
Selznick, P. (1992) 'The Moral Commonwealth: Social theory and the promise of community'. Berkeley, University of California Press.

Special Commission of Inquiry into Child Protection Services in NSW. (2008). Public Forum Transcript. Retrieved October 14, 2009 from

http://www.lawlink.nsw.gov.au/lawlink/Special_Projects/11_splprojects.nsf/vwFiles/DOC080

\section{PDF/\$file/DOC080424.PDF}

Stanley, J., Tomison, A. and Pocock, J. (2003) 'Child abuse and neglect in Indigenous Australian communities', Child Abuse Prevention Issues, 19, National Child Protection Clearinghouse, Australian Institute of Family Studies, Melbourne.

Tilbury, C. (2008). The over-representation of indigenous children in the Australian child welfare system. International Journal of Social Welfare, (Early View).

Tyler, T. (1990) Why People Obey the Law: Procedural Justice, Legitimacy and Compliance, New Haven, Yale University Press.

Tyler, T. (1997) 'The psychology of legitimacy: A relational perspective on voluntary deference to authorities', Personality and Social Psychology Review, 1(4), 323-45.

Tyler, T. (2008) Psychology and Institutional Design. Review of Law \& Economics, 4(3), New York University.

Vardon Report (2004) The Territory as Parent - Review of the Safety 
of Children in Care in the ACT and of ACT Child Protection Management, Canberra, ACT Government.

Wild, R. and Anderson, P. (2007) Ampe Akelyernemane Meke Mekarle 'Little Children are Sacred:' Report of the Northern Territory Board Of Inquiry Into The Protection Of Aboriginal Children From Sexual Abuse.

Wood Report (2008) Special Commission of Inquiry into Child

Protection Services in New South Wales, Sydney, New South Wales Government. 




